\title{
THOSE WHO HAVE LOVED ARE THOSE THAT HAVE FOUND GOD: QUEER SIKH NARRATIVES IN SAB RAB DE BANDE (WE'RE ALL GOD'S CREATION) (2020)
}

\author{
Regiane Corrêa de Oliveira Ramos \& Jairo Adrián-Hernández \\ Universidade Estadual de Mato Grosso do Sul (Brasil) \& Universidad de La Laguna
}

\begin{abstract}
Religion and non-heterosexual and gender identifications have a complex relationship in most societies. The religious discourse in most communities condemns the LGBTIQ+ community and even deny them to access and practice their religious experiences/practices. In India, where religion and rituals are embedded in daily practices, religious identity can rarely be disassociated from other identities and added factor like caste and social class. India is if anything saturated with hundreds of religions which translates into multiple identities, sometimes overlapped and in confliction with each other. In this context, the purpose of this paper is to analyze the documentary Sab Rab De Bande (We're all God's Creation) (2020) produced and directed by Sukhdeep Singh to highlight the challenges that the queer Sikhs in India face when reconciling their religious identity with gender identities and sexual orientations. The corpus of this analysis sheds light on intersectionality, which allows us to see the collision of structures and the simultaneous interaction of identity avenues.
\end{abstract}

Keywords: LGBTIQ+, Masculinity, Femininity, Punjab, Queer Narratives, Sikhism.

\section{SOLO AQUELLOS QUE HAN AMADO HAN ENCONTRADO A DIOS: NARRATIVAS \\ QUEER Y SIKH EN SAB RAB DE BANDE (TODOS SOMOS HIJOS DE DIOS) (2020)}

\section{RESUMEN}

La relación entre religión y otras disidencias de sexo y género suelen desarrollarse de manera compleja en muchas sociedades. El discurso religioso condena y persigue a la comunidad LGBTIQ+ e incluso les niega el acceso a sus espacios y narrativas. En la India, donde religión y rituales se integran incluso en las dinámicas costumbristas, las identidades religiosas no pueden entenderse sin otros factores como casta o clase. India es, ante todo, una región con cientos de religiones, lo que se traduce en múltiples identidades, que, a veces, se solapan o confrontan. En este contexto se mueve nuestro trabajo, que busca analizar el documental Sab Rab De Bande (Todos Somos Hijos de Dios) (2020), producido y dirigido por Sukhdeep Singh, para acercarnos a los desafíos que afronta la comunidad Sikh LGBTIQ+ en India al intentar reconciliar sus identidades religiosas y sexuales. Nuestros resultados parten de la interseccionalidad, lo que nos permite indagar en la colisión de estructuras e interacciones de estas trenzas identitarias.

Palabras clave: LGBTIQ+, masculinidad, feminidad, narrativas Queer, Punjab, Sijismo.

DOI: https://doi.org/10.25145/j.recaesin.2021.83.10

Revista Canaria de Estudios Ingleses, 83; November 2021, pp. 131-149; ISSN: e-2530-8335 
The clay is the same, but the designer

has fashioned it in various ways

Nothing is wrong with the pot of clay

And there is nothing wrong with the potter

\section{Guru Granth Sahib}

The Creator, in the epigraphy, indicates diversity as a principle of His creation. Sikhism, like all Karmic faiths ${ }^{1}$, recognizes diversity. It believes in the equality of all human beings. Ek Omkar, 'God is one', is central to the Sikh doctrine. Although the holy book, the Granth Sahib, subscribes to equality and inclusivity, queer Sikhs ${ }^{2}$ are discriminated against. Talking about gender identity and sexual orientation plays an important role in the maintenance of an inclusive world. The aim of this paper is then two-fold. At a first level, we seek to analyze Sab Rab De Bande (We're all God's Creation), a documentary about the life stories of five LGBTQ+ Sikhs living in India. And simultaneously, we discuss around the inseparability of both religious and sexual and/or gender identities. To that end, we have tailored this paper in two sections that are in turn titled after Guru Nanak's teachings, just like the title of this paper. One that provides with a very rudimentary sketch on the history of Sikhism, although there is an especial interest here in its approximation to noncisheterosexual realities. Then we dedicate one epigraph to rescuing some of the narrations that appear in the documentary, but always from a critical viewpoint that navigates between post- and decolonial postulates and the queer condition. Finally, we complement our investigation with an annexed interview with the director himself. This can be found in this very same journal, within the "Interviews" section.

The documentary Sab Rab De Bande (We're all God's Creation) explores the intersections and dissidences resulted from being queer and religious in the Indian state of Punjab. It premiered at Reel Desires, Chennai International Queer Film Festival, on December $5^{\text {th }}, 2020$. Based on interviews, the film narrates the lived

${ }^{1}$ Hinduism, Buddhism, Jainism and Sikhism are considered karmic faiths because they are based on the belief of rebirth (karma). For further reading on the distinction between Karmic faiths and Abrahamic faiths, see Devdutt Pattanaik's discussion on the website https://devdutt.com/ articles/karmic-faiths/.

${ }^{2}$ Queer is not only defined as an identity, but also seen as a dissent from and defiance of dominant meanings of sex and gender. It is an ongoing critical engagement of and resistance to the establishment and maintenance of cisheteronormativity. Teresa de Lauretis transformed the term 'queer' (in English, a strongly derogatory and vulgar term) into a concept in the 1990s. From a pejorative term, queer now is a reclaimed political term for those disrupting the normalized standards of gender and sexuality. It is often self-selected by those who either object to or prefer to a nongender-specific term such as 'gay' and 'lesbian'. It has also been used to quantify those who go against normal convention, so it is not necessarily attached to sexual orientation and/or gender identity. In the Indian context, as Devdutt Pattanaik points out, words such as 'napunsaka', 'kliba', 'pandaka', 'pedi', 'kinnara' and 'kothi' conservatively refer to the third gender (in terms of body or physical characteristics) but can also be literally translated to include sexualities (feelings or phsychosexual characteristics) across the queer spectrum. 
experiences of Amolak Singh, Sukhdeep Singh, Ekampreet Singh, Ritika Shergill and Puneet. The documentary starts with a panoramic view of Sikhism and Sikh culture from the Gurudwara Bangla Sahib in New Delhi and then moves on to tell the stories of these Sikh followers and their conflicts interacting with Sikh community. Next, it shows the narratives of exclusion in Sikh spaces such as families, gurdwaras, and other social institutions. This is a critical element of the film because it exposes cis-heteronormative discourses and practices which discriminate queer Sikhs based on their gender and sexuality.

The documentary is directed and produced by a software engineer, Sukhdeep Singh. According to Singh, it is the first visual material on queer Sikhs in India (Singh, 2020). As the Sikhs are a minority in India and the queer Sikhs are a minority within this minority, it was "extremely difficult" for the documentary maker to find subjects for the project, and it took him four years to complete it. Because of the small size of the community, which is also very close-knit, Ekampreet and Puneet had reservations about revealing their identities (see interview). The interviewees, who come from different parts of India, have different gender and sexual identities. Amolak, Sukhdeep and Ekampreet identify their sexual orientation as gay, Ritika self-identifies as a trans woman and Puneet declares to be a lesbian. All of them assert the inseparability of religious identity and gender/sexual identity. All of them perform different masculinities and femininities, breaking down conventional gender roles. As femininities and masculinities are plural and dynamic, they change with culture and with individuals. Amolak loves going to the gurudwara and performing sewa in a number of ways such as cleaning the place, serving food at the langar, and washing the dishes. His gender expression is androgynous. Having the characteristics of both male and female, he breaks the stereotypes of a Punjabi man which are generally expressed in aggression, militancy and rusticity. He, for example, applies make-up and wears accessories. This, as he remarks, makes him "feel confident and beautiful" (Sab Rab De Bande).

\section{HE WHO HAS NO FAITH IN HIMSELF CAN NEVER HAVE FAITH IN GOD: AN INTRODUCTION TO SIKHISM}

This section opens with an austere introduction to Sikhism. Literally, the Sikh community ( $k h a l s a$ ) means the community of the pure. While being queer can be difficult for any person in India irrespective of their religious background there is an additional problem here; Sikhs are a unique minority in India. The current Sikh population in India stands at 20.8 million, corresponding to only $1.72 \%$ of the country's total population. The Sikhs are predominantly located in Punjab, but also live in many other parts of India, and their primary language is Punjabi. According to the 2011 Census, Sikhs constitute $57.69 \%$ of Punjab's population, followed by Haryana (4.91\%), New Delhi (3.40\%) and Uttarakhand (2.34\%). Outside of India, Canada has the largest Sikh population in the world, with 468,670 Sikh residents $(1.96 \%)$ and the United Kingdom has the second largest Sikh population in the world, at 342,429 Sikhs. 
Sikhism is one of the youngest major religions of the world. It is, as Khushwant Singh states, "born out of a wedlock between Hinduism and Islam after they had known each other for a period of nearly nine hundred years" (16). The new religion, he added, "began to develop a personality of its own and in due course grew into a faith which had some semblance to Hinduism, some to Islam, and yet had features which bore no resemblance to either" (16). The author remarks that the founder of Sikhism Guru Nanak challenged not only the principles of these two religions but also "defied convention and lived the life of a nonconformist in a highly conformist society" (35). He was a religious reformer attempting to break down centuries-old, rigid codes of faith ideologies, practice, and culture in India in the late fifteenth and early sixteenth century. He was succeeded by nine other gurus: Angad Dev, Amar Das, Ram Das, Arjan Dev, Hargobind, Har Rai, Har Krishan, Tegh Bahadur, and Gobind Singh. In 1708, the tenth Guru passed the succession to a holy scripture, Guru Granth Sahib, which is considered to be the living Guru. The holy book is a set of hymns to be contemplated upon. Sikhism believes in God and soul, but, as Devdutt Pattanaik acknowledges, they are distinct (Pattanaik 2017). God is formless, before whom all are equal. Sikhism, he argues, "values devotion and service as the means to earn God's grace and break free from the wheel of rebirth" (31).

The three pillars of Sikhism are: Naam Japna (Meditating on the name of God. This is done by reciting the Guru's hymns each day and remembering Him in one's thoughts and deeds), Kirat Karni (Living an honest and truthful life) and Vand Chakhna (Vand means to share and Chakhna means to consume. Sikhs are advised to share their wealth with others. Thus, donating it to the larger community is an essential part of Sikhism). In Sikhism, worship is a way of life. The followers believe that they should dedicate their lives to Waheguru (God) and follow the teachings of the Guru Granth Sahib. Their place of worship is called gurdwara. The Golden Temple (The Harmandir Sahib) in Amritsar, a city in North-Western part of Indian, is their main site of worship. Present in the Harmandir Sahib is the original Adi Granth, the first version of the Guru Granth Sahib, which was compiled by Guru Arjan. Each gurdwara has a langar (kitchen) in which free meals are served to everyone, regardless of their caste, gender or wealth. The langar is run by volunteers, who can be either male or female. It is important to highlight that the community kitchen (langar) originates as a protest against the Hindu caste system:

[T] he Bhaktas had paid only lip service to the ideal of casteless society; Nanak took practical steps to break the vicious hold of caste by starting free community kitchens - guru kà langar-in all centers and persuading his followers, irrespective of their castes, to eat together. Nanak's writings abound with passages deploring the system and other practices which grew out of caste concepts, particularly the notion held by Brahmins that even the shadow of a lower-caste man, on a place where food was being cooked, made it impure. (Singh 40)

The rejection of caste is also exemplified by the distribution of the karah prasad, the blessed food. Karah is a type of whole wheat flour halva made with equal portions of whole-wheat flour, clarified butter, and sugar. It is distributed to 
everyone at the ends of services, symbolizing the belief in equality and the oneness of humanity. ${ }^{3}$ Performing the sewa is very important to Sikhs. It means a selfless service that involves helping others without any reward or personal gain. According to the Guru Granth Sabib, "One who performs selfless service, without thought of reward, shall attain his Lord and Master" (286). There are three types of sewa: tan, man and dhan. The first is a physical service that can be done, for example, working in the langar (kitchen). The second is a mental service that can be performed by teaching the Guru Granth Sahib. The third refers to a material service which means to give to those in need. The Sikh family name, Singh and Kaur, demonstrates another aspect of a casteless society. Deriving from the Sanskrit simha, Singh means lion and it is a common male surname. A Sikh woman takes the surname Kaur which means both a princess and lioness. ${ }^{4}$ As mentioned by Punnet, a lesbian woman in the documentary itself.

Sikhs are required to keep the 'five ks,' as markers of their initiation (Amrit Sanskar) into the brotherhood. The initiators (Amritdharis) have to maintain these five emblems, These emblems together symbolize that the Sikh who wears them has dedicated themselves to a life of devotion and submission to the Guru. The symbols have become greatly more powerful with each passing year of Sikh history as they are a phenotypical logo for this community all around the globe. These symbols connect and gives Sikh authenticity whenever they go as it happens with other societies: the keffiyeh, the agal, the thawb, or the fez, to name a few. But these emblems prescribed for khalsa by Guru Gobind Singh (1666-1708), which are:

[T] hey were to wear hair and beard unshorn (kes); they were to carry a comb $(k a n g h \bar{a})$ in the hair to keep it tidy; they were always to wear a knee-length pair of breeches (kach), worn by soldier of times; they were to carry a steel bracelet (karā) on their right wrist; and the were to be ever armed with a sabre (kirpann) In addition to these five emblems, the converts were to observe four rules of conduct (rahat): not to cut any hair on any part of their body (this was a repetition of the oath regarding the kes); not to smoke, chew tobacco, or consume alcoholic drinks; not to eat an animal which had been slaughtered by being bled to death, as customary with the Muslins, but only jhatka meat, where the animal had been despatched with one blow; and not to molest the person of Muslim women. (Singh 81)

In the introduction to I am Divine So Are You: How Buddhism, Jainism, Sikhism and Hinduism affirm the dignity queer identities and sexualities, Pattanaik

3 Although Guru Nanak's teachings disapprove the caste system and other practices which grow out of it, the caste system is present in the Sikh community. For further understanding of it, see the documentary "India Untouched: Stories of a People Apart" (Sytalin 2007). It exposes the continuation of caste practices and Untouchability in Sikhism, Christianity and Islam, and even among the communists in Kerala.

${ }^{4}$ In "The Birth of the Khalsa: A Feminist Re-Memory of Sikh Identity (2005)," NikkyGuninder Kaur Singh looks at the basic texts and tenets of Sikh religion and exposes the female aspect in the sacred text, daily prayers, dress code, and rituals of the Sikhs. 
points out that karmic fatihs approach the idea of queer very differently from Abrahamic fatihs (Pattanaik 2017). While the former subscribes "to the doctrine of diversity" -everyone is unique because of the varying karmic burden", the latter subscribes "to the doctrine of equality- everyone is equal before the eyes of God" (28). Pattaniak remarks that faiths "affirm the dignity of queer people" and also "empower them psychologically, which enables them to thrive politically and economically". Besides this, they "reduce queer-phobic tendencies in neighbourhoods where they live" (26). Karmic faiths also look at scriptures differently from Abrahamic faiths. They put emphasis more on ritual practice rather than on interpretation of the scripture. The major focus is on experience rather than on understanding. In Sikhism, for example, "doing service (sewa) and listening to praise of the lord (simran) is more important than analysing the writings and the tales of the gurus" (47). The Sikhs are a community with a very strong sense of oneness, with the ideas of service and togetherness and the ideals of equality forming the core of their belief system and social behavior. It reflects the most in the way the religious is practiced, especially in gurdwaras, which serve as temple as well as place of community gathering and sewa (service).

Sikhism, as Pattanik argues, separates the theological (Karmic faiths) from the administrative (Abrahamic faiths) and this has implications in understanding the world, and mainly the gender. He writes:

The holy scriptures are part of the theological world and in them genders are equal, the householder's life is valourised over the hermit's, and there is talk of the soul being genderless; they contain no comment that is hostile to queers. In the administrative real, queer is invisible, with laws neither including nor excluding them. Hostility towards homosexuality in Sikhism is more an outcome of general patriarchy in society and personal prejudices than a requirement that can be traced back to the faith. (48)

As it has been argued by many scholars, laws against homosexuality and transsexuality are not related to Hindu, Buddhist, Jain, and Sikh scriptures, but to Victorian moral and laws. In Sikh scripture and Sikh hymns there is nothing against queer genders or sexuality. They only value marriage and the householder's life.

\section{THE WORLD IS A DRAMA, STAGED IN A DREAM: RECONCILING SEXUAL AND RELIGIOUS IDENTITIES}

The precolonial trajectory of homosexuality in India seems to move into a relatively tolerant position towards any sexual dissidence and both literary and archeological presence only subscribe to our thesis. The Kama Sutra, Urdu poetry, Hindu mythology, or the Khajuraho temples are only few of such examples. It is salutary to bear in mind that it was only after the arrival of Europeans that queerized bodies were problematized and tabulated from Western lenses, and by implication, criminalized. E. Han and O' Mahoney (2014) insist that these legislative codes aimed firstly to protect British administrators from 'sodomy' but 
it also gave missionaries control over the regulation of interpersonal modes and so it catapulted the proselytizing agenda (6). This institutionalized persecution still echoes in postcolonial India as section 377 was done away in 2018. But let us direct our attention to a task to which little attention has so far been given, that is queer identities within Sikh communities.

In the context of the teachings and values of Sikhism, we now look at how they shaped the worldview of Sukhdeep Singh who was born and raised in a Sikh family. He writes openly about gender and sexuality and is producing a digital archive on Sikh queers on Gaylaxy, an online magazine that he founded as a student in January 2010. The inaugural 2010 issue brought forth the article "A New Dawn" which tracked down the history of the LGBTQ+ movement in India (Singh 2010). Since the launch of this magazine, he has written many articles ranging from civil rights to public policies for LGBTQ+ folks. In 2012, Singh wrote a piece titled "Why LGBT Sikhs should come out," which encouraged queer Sikhs to open about their sexual orientation and gender identities (Singh 2012). Additionally, in 2016, his viral article "Homophobia has no place in Sikhism" criticized the decision of the Shiromani Gurdwara Parbandhak Committee (SGPC) for not offering the traditional Sikh siropa (robe of honor) to Ontario Premier Kathleen Wynne due to her views on same-sex marriage (Singh 2016). The SGPC upheld the resolution arguing that "offering her (Wynne) a 'siropa' would be against Sikh ethics" (Singh 2016). However, for Sukheep, SGPC's arguments had no theological logic, stating,

[I]it must be pointed out that while announcing their decision not to present Wynne with a siropa, neither the SGPC, nor anyone else has cited on what theological basis have they made the statement. One would expect that when such a body makes a decision which will affect millions of LGBT Sikhs, they would base their decision on the teachings of the Gurus, or the banis composed by them. Yet, alas, their own biases and homophobia is passed off as "Sikh ethics" without quoting from any of the Granths, or the teachings of the Guru. (np)

Sukhdeep Singh's arguments above point out that the committee's decision is not based on the principles of Sikhism. They are influenced by patriarchal heteronormative discourses and practices which condemn same-sex marriages. The main tenet of the teachings of the Gurus is equality and inclusivity. Singh contends that Sikhism celebrates diversity, as it is demonstrated in the epigraph of this paper. For him, the great virtue of Sikh philosophy is the importance it places on acceptance. In "Sikhism: All Humans are created equal," he affirms "unlike Hinduism, which is replete with stories of queer encounters and gender fluidity, the Sikh attitude towards queer individuals can only be surmised through interpretations of teachings and events in the lives of the Gurus" (92). When SGPC condemns homosexuality, Singh asserts, "they are basically asking LGBT Sikhs not to accept the way God made them" (2019). He widens the debate by separating Sikhism and Punjabi culture by raising the point if the hypermasculinity of the 
Punjabi culture 5 speaks for Sikh beliefs. While respect to difference is embedded in the teachings of the former, conservatism and patriarchalism(s) permeate the culture of the latter.

Contemporaneity presents itself to challenge cisheteronormative discourses, as there is not a single passage against homosexuality or transsexuality in the Guru Granth Sahib. As the historian Pashaura Singh affirmed, "all interpretive activity is subject to particular cultural predispositions, the historical situation of the interpreter, inevitable change in the modes of attention and the nature of interaction between the past and the present" (240). He also added that the reader can approach the "text without preconceived intentions in order to explore the many possibilities of its meaning and confront the world in front of the text" (260). According to him, the reader constructs meaning-making to the text. It involves interference, making choices and changes, breaking down pre-established meanings and creating others. Sukhdeep Singh, with the documentary, provides a thorough critique of the cisheterosexual interpretations of the Sikh scriptures, considering gender violence and LGBTQ+phobia. As a gay Sikh himself, he argues for the necessity of an anti-LGBTQ+phobic Sikh community and a change to the resistance of heteronormativity. Singh wants to assure other young queer Sikhs that one can be gay/lesbian/androgyne/bisexual/trans/asexual and Sikh. Through his activism, he asserts there is no single way of living the Sikh faith and being Sikh. This is evidently shown in his documentary as he highlights the lives of five queer individuals. ${ }^{6}$

Sadly enough, not much ink has been spilled on this topic or, in other words, the intersectionality between these two identities (that is religious and gender identity/sexual orientation). Mostly because queer Sikhs have been silenced and closeted for years. The following lines are then an approximation to some experiences that have contributed to the formulation of this bifold identity and that, in our mind, bridges the existing gap of such a bibliographical archive. Masculinity, or mardangi, is uncannily prefigured in the dynamics of such patriarchal society, as repeated by most interviewees in the documentary. This masculine construction, as delivered by Garha (2020), is "directly related to men's ability to meet their household needs, and have control over women" and that even the turban is a sign for masculinity within upper-caste Sikhs. (4-5) Another complementary observation is that Guru Gobind Singh turned the Sikhs into a martial community of fighters and gave them a unique identity. In "Locating the Sikh Pagh," Virinder S. Kalra observes that later the British, during the colonial period, also incorporated them into a 'martial race', constructing a Sikh hypermasculinity against an effeminate Hindu masculinity (2005). This masculine colonial construction is also mentioned in the film,

${ }^{5}$ For a further reading on toxic masculinity in Punjabi Culture, read the article "The Punjabi Jatt Hero And Other Toxic Masculinities In Punjabi Culture" (2020) where Anirban Chanda and Sahil Bansal analyze the representation of Punjabi masculinities in Indian films and songs.

${ }^{6}$ For further discussion on this topic, watch the video Power of Pride: Queer \& Sikh (Logo 2019) in which another group of queer Sikhs, based in the United the States of America, discuss the importance of reconciling religious identity and queer identity. 
The valor and bravery of the Sikh community was recognized by the British too regiment in the Army which continues to date in the Indian Army as well. This has also created a very macho image of the Sikh men in society, something that LGBT Sikhs find hard to break. As a Sikh, you are supposed to be macho, one who takes out a sword and fights. (00:05:21-00:05:51)

Decolonial thinkers (Lugones 2010, Oyèwúmi, 1997, or Segato 2010) have largely debated around the resonance of cisheteropatriarchal codes in colonial venues. They conclude that the gender binary paradigm has been inorganically transplanted into these scenes, where gender was originally performed with certain fluidity. And so Europeans also transported certain modes of socialization around the ideas of femininity and masculinity that jeopardized the Sikh reality. For Raewyn Connell, different historical periods establish a hierarchy of masculinities in all human societies (2005) and modern India, that is still licking from its colonial wounds, is investigating these ancient modes of gender representation that goes beyond canonical and binary understandings. We find in this documentary queer Sikhs that question and challenge these hierarchies: "My gender expression is androgynous. Androgynous means, like, you have both the characteristics, you have nature of both the genders like the nature of female as well the nature of male as well." (00:06:49-00:07:02).

Related to this hypermasculinity is the dastaār, or turban, one of the most immediate traits for Sikhism. The bearded turbaned man comes from the first emblem mentioned above. The turban is a mandatory symbol of the Sikh religion. It has "a wide variation of styles, colors, material, sizes, and even uses between Sikhs from varying diasporic locations, class backgrounds, and even genders -for Sikh women may also don turbans" (Paur 48). ${ }^{7}$ In 2014, after debuting in the Bengaluru Pride with a rainbow turban, Sukhdeep Singh went to the Golden Temple wearing the pride turban. Singh acknowledged that it got "caught many people's attention", but he does not believe that "anyone understood its significance" (Singh 2020). To him, this performance was quintessential as a Sikh dissident as it "would merge my two identities into one." (Singh 2020c). In "Understanding turbans: Don't link them to terrorism," Eli Sanders notes that the fabric headwraps and head coverings are common in a many other parts of the world, from North Africa across the Middle East and into Central Asia, and all the turbans are not the same (Sander 2001). It is to this différance, in Derridean sense, that both Sanders and Singh emphasize that we turn now. The turban has, as Jasbir K. Kaur explains,

witnessed as an appendage that is total of its being-perceived, it is often represented by the weaver as part of his or her body, and not as an appendage or thing that has properties and qualities separate from the body. The horizontal axis of 'actions and passions' between bodies reveals the 'phenotypical encounters', but also implodes

\footnotetext{
${ }^{7}$ Normally Sikh women wear chunnildupatta, but some women, especially amritdhari (baptized), wear also a turban.
} 
bodies from within, shooting through and past bodily boundaries. Accomplice to this is the representation of the turban as 'part of the body'. (66)

The queer Sikh bodies weave it pinning the body in social dynamics and social dynamics in the body (Connell 2016). To understand the social embodiment, as Raewy Connell asserts, is to recognize the agency of the bodies (colonized and dehumanized). For Connell, social embodiment is neither a reflection nor reproduction or signature. It is "a process that generates, at every moment, new historical realities: new embodied possibilities, experiences, limitations and vulnerability for the people involved" (49). With Sab Rab De Bande (We're all God's Creation), Singh inserts the turbaned queer body into the temple/Sikh community and exposes the "multitudes of queer" Sikhs, dealing especially with the geopolitical displacement processes of the queer and/or of what would be a queer located in the Sikh Culture (Preciado 2003). Also, Sukhdeep Singh's rainbow turban becomes a reference as well as a banner for the rights of queer people within the Sikh community.

Returning briefly to this interweaved identity, we find also fascinating the words of Prabhdeep Singh Kehal in an interview with Logo (2019) when he says that, during Pride, instead of celebrating, Sikhs stay at home and mourn. June coincides with the massacre that occurred at the Golden Temple in 1984, also known as Operation Blue Star, when Indira Gandhi directed a military operation to remove Sikhs from the temple, an event that is also mentioned in the documentary. And, whether by accident or design, they are reconciling these two confronted identities. While in the West we celebrate Stonewall and the figures of trans women of color such as Marsha P. Johnson or Sylvia Rivera, queer Sikhs are now intertwining experiences and working in the construction of their identities away from Western gesticulations. In a similar note, Sukhdeep Singh also offers us a testimony of a trans woman who instrumentalized religious practices for transitioning. She told her parents to cut her hair like a boy so she could shave her beard too (00:07:56-00:08:43). Narratives such as these two here add to the repertoire of discourses resulted from being queer and Sikh as they are autochthonous to this community.

All the five persons whose narrative is included in the documentary do not see their religious and queer identities in conflict and seek acceptance from the community-despite being rejected or not accepted-on the basis of teachings of their religion. On the contrary, some of them justify their queerness by religious means, phenomenon described by Humphreys (1972) as 'stigma redemption,' "if God made male, female, then he surely has made transgender as well, God never discriminates based on your physical appearance." (00:16:12-00:16:18) or, in the words of the director,

The idea of Sikhism that I grew up with was a very accommodating and inclusive one. Thus, I never felt any conflict between my own religious identity and my sexuality. I was Sikh, and later I realized I was gay, and both of these were part of me, and I did not think being one meant giving up on the other. (Singh 2020c) 
Also, some Sikhs in the diaspora confirm that there is no need for these two identities to be apart, but rather that Sikhism amalgamates both from a spiritual realm, ${ }^{8}$

Sikhi is a way for them not only to connect with the Guru but also preserve the connection to culture and religion that has been bestowed upon them by family. Sikhi places a great importance on the belief that the human race is all equal, regardless of gender, religion, race, nationality, or sexual orientation. The light of God resides within every one of us, and the aim of Sikhi is to allow us to connect with the One inside of us. (Sidhu 2019)

This makes the case of queer Sikhs different from LGBTIQ+ people from other religions and communities, especially the majority Hindus, who may be at times be in conflict with their religion or do not assert their religious identity while seeking social acceptance as a queer. In this sense, this documentary has explored the meaning of being a sexual minority inside a community that is itself outnumbered by others. The director then takes the viewers into the life and death struggles of those who, excluded and shamed by orthodox Sikhs, must operate their own embodied existence, securing the conditions for their own lives. Amolak Singh, Sukhdeep Singh, Ekampreet Singh, Ritika Sergill and Puneet develop within their own language an understanding of being Sikh and queer, their own bodies as sites of desire and affliction, modes of persistence linked to communities of belonging, and a subtle practice of subversion in relation to institutions from which they are excluded.

Even though the people interviewed here aim to reconcile their experiences as Sikh and queer, it is mandatory on our part to provide with some of the narratives that appear in this film and that are less diplomatic, to say the very least. Amolak, for example, tells the camera that "Just as I entered the Gurudwara, there was a group of boys who were serving langar (food). He was serving tea and all of a sudden, he saw me and he said 'from where did this @\#@\#\% come?' That comment that he made... still pain is there" (00:21:46- 00:22:02). Ritika also elaborates on her experiences as a trans woman in a religious site, "it happens that when we take Prasad (Holy offerings) those who are distributing it give it from a distance so that their hand doesn't touch us. Also if we are doing sewa (religious service) and cleaning utensils they say 'No, no, it's fine'." (00:21:46- 00:22:15). Stigmatization towards sexual dissidents on the part of religious institutions seems a universal anecdote. These are not isolated cases, but rather a routine for those who, besides being religious, are also queer. This ultimately leads to contradictory sentiments and hostility that might affect the believer's channels of identification: internalized homophobia, dysphoria, or heterocentrism. It has been demonstrated, after all, that religiosity

${ }^{8}$ For further reading on Sikh diaspora, see The nation's tortured body: Violence, representation, and the formation of a Sikh "diaspora" (2001). 
raises prejudicial attitudes as well as detrimental consequences for the LGBTIQ+ community (Cragun \& Sumerau 2015). These tensions, reports Yvette Taylor (2016),

[...] between 'self-cultivation' in religious subjectivisation and 'life-as' demands where gendered and sexualized scripts recirculate certain sources of authority. These positions can occur at the same time as queer people may not officially be welcomed or legitimised in the institutionalised church (as audiences, listeners, leaders [...]), which in turn occurs in the midst of queerer places of religion. (7)

We also find two stories in this film that are no doubt part of a dangerous discourse that aims to invert sexual orientation and/or gender identities through corrective violence. This violence could be not only physical but also sexual, medical, psychological, emotional and even cultural. These do not operate exclusively but they are rather reproduced dynamically. But let us exemplify the aforementioned with two narratives extracted from the film itself. Rikita, also invoked in the paragraphs above, tell us the following,

They didn't understand what was happening. They thought may be someone has performed black magic. They took me to Babas (local quacks) thinking that may be I would change. Then in February a very big incident happened with me... By that time I had already had sex change operation and all other things. My mother called me home deceitfully telling that "I am very sick, please come and visit me". And then they put me forcibly in a drug de-addiction camp for three months. Among 74 men, I was all alone... I used to be given sleeping injections... People would have sex with me at night and I wouldn't even know But when I would finally gain consciousness after 2-3 days all my body parts would hurt. (00:10:08-00:10:56)

This testimony presents itself problematic in numerous ways. Firstly, her mother draws a parallelism between her daughter's gender identity and black magic. We will not enter into discussing her intentions but such correlation is endemic to the LGBTIQ+ community: "Viviane, who was raised to believe her same-sex attraction meant she was bewitched. Her family's response: to chain her to a wall to be raped by a man who they forced her to marry." (Sobel 2018). And other testimonies as Sohail Ahmed's, whose father forced him to undergo an exorcism to cure him from homosexuality (Hanif 2015). Then Rikita goes into saying that she was in a rehab center where she was both medically and sexually assaulted. As it also happens with other LGBTIQA+ individuals all around the globe: conversion therapy, corrective raping, electroshock, pharmaceutical violence, or lobotomies, to name a few.

Puneet, a lesbian woman from Punjab, also suffered from her family's emotional blackmailing. Her father, who was very sick, insisted that she would get married. While marriage, or anand karaj, within Sikhs seems to be more egalitarian than other religious philosophies, as far as they refuse derogatory practices such as dowry or purdah (Mahajan et al. 2013), it cannot escape from its patriarchal significance. And in the case of Puneet we venture into saying that there is a homophobic impulse too. Marriage is expected for cisheterosexual women, but in the case of lesbians it also has a conversing significance. Mustikan has recognised that, 
In Britain, forced marriages among Pakistani, Indian and other communities has obliged the government to launch the Forced Marriage Unit (FMU). Though the FMU distinguishes between a marriage of convenience of gay and lesbian couples as being different from a coerced marriage, in reality the former-where true love is essentially missing-are also forced, not by family in this case, but by social and cultural and religious expectations. The FMU has detailed some cases to underscore the disastrous impact on those within the LGBT+ community who are married against their wishes, after effectively becoming a victim of human trafficking at the hands of their families. (2019)

And even now that her mother accepts her, she lives in constant anxiety: "In fact, before my brother's marriage she herself told my cousins and all relatives not to ask me about my marriage as that would upset me. And all the time, I kept thinking that they will push me again for marriage." (00:14:50- 00:15:09). This fear is not un reasonable if we consider that forcing LGBTIQ+ people into cisheterosexual marriage is common in India. Sukhvinder's parents, after knowing about his sexual orientation, took his passport and money, forcing their son to marry a girl already chosen from the village. (Mustikan 2019) And this is only one of many stories also located at the FMU webpage like Yasmin's, Farhan's, whose parents thought that marrying a woman would correct his sexuality, or Maya's, who compares corrective marriage to "being sold to be raped".

Dating apps have also proved themselves an alternative for the interaction between members of the LGBTIQ+ community. There is little doubt when we say that, at a sociological and even anthropological level, queer dissidents interact in ways that scape cisheteronormative understandings and that this queer-socialization occurs in scenarios that are far from inviting. If Lacan speaks of recognizing oneself in the mirror, being a dissident subject with no references that you can relate to, only obscures the experience. This feeling is also gathered in the documentary when said "are there any other gay Sikhs around?" (00:04:42). The public is, for some, a neglected territory, and so technology has become a vehicle for the transportation of queer codifications into a domestic realm (socialization, culture, sex practices, romantic narratives). Grindr, named in the documentary and perhaps the most downloaded app among gay men, provides a platform as it connects people from the safety of their homes and, if desired, anonymously. It creates somehow an online community and brings some experiences and narratives together.

That is the theory, but reality proves otherwise. In 2017, Egyptian police hacked Grindr for tracking gay men in the country and imprison users indiscriminately (Jankowicz 2017). The infiltration of cisheteronormative regulations into these spaces also needs to be called into question. It is common to find profiles that only join in conversation with masculine, normative and straight-looking men, then discriminating against other ways of gender and bodily expression. In a not so much positive light, Sukdeeph Singh also elaborates in the problematics of such app and concludes that, especially in India, gay Sikhs are being virtually attacked and marginalized. He provides a series of screenshots from different profiles where users make clear that they would not date Sardars (00:22:41-00:22:43) or even question 
their religious sentiments because of their sexual orientation (00:24:12-00:24:16). Little has been written about religious minorities on Grindr, as literature rather focuses on racial issues but, in this fashion, Andrew DJ Shield (2018) provides us with a thorough discussion on this fascinating topic and he gathers that there are two significant phenomena that occur when racialized gays claim for these spaces.

Firstly, minorities are addressed as a sexual fetish ("I'm into Asians"), which Sukheeph Singh himself subscribes in a public interview organized by the Brasil-India Associação de Redes de Conhecimiento (Brazil-India Knowledge Networks Association, São Paulo) as well as in an interview for Salzburg Global Seminar: "Then there were others who only looked at Sikh men as very muscular and well-endowed and wanted to fulfill their fantasies." (Singh 2020c). And it is also mentioned in the film as the director makes us look at the world not only as marked by the material experiences of colonization, exploitation, and economic and political dependence on the Global North but also through the lenses of those marked by the cultural experience of being categorized as exotic. And, on a second note, that people of color are insulted and harassed because of the race, nationality or religion (Shield, 150-152),

It is not just the wider Sikh community that LGBT Sikhs have to battle against. Discrimination against Sikhs within the LGBT community is rampant as well. Where profiles on dating apps often mention No Sikhs and No Sardars (turbaned Sikhs). This can have its own psychological effects too. When it comes to you know probably dating gay Sikh men and going out with them. A lot of discrimination is there. (00:22:28-00:22:55)

One may be then confused as to why Sardars are being discriminated when, genetically speaking, they are not much different than a Hindu. In some cases, these categories earlier mentioned (that is nationality, race, and religion) are understood by others as a whole. And so Sikhs are not only presumed as a religious group but also 'cartographied' in certain areas (Punjab, in this case) and taxonomized into a racial subdivision that is alien to Indian genetics. Actually, Shield provides us with examples that confirm our words. He gathers some testimonies from religious minorities who are also active on Grindr: "F*ck you [Arab country], f*ck Islam, $f^{*}$ ck you" (151). If assumptions are often made around your religious status based on your skin color and/or nationality, in the case of gay Sikhs this is even more jeopardizing because the turban and the beard work as immediate signs for Sikh recognition. And this, concludes Sukhdeep Singh, "led to a lot of insecurity within me." (2020c). He believes that because of being Sikh "no one would ever want to date me, causing to a lot of body-image issues that took a while to go." (ibid).

\section{CONCLUSIONS}

The conclusions of this analysis make a case for its initial considerations. It is verified that Sikhs are themselves a minority in the world, but LGBTIQ+ Sikhs are The Other within such minority. Not to mention other overlapped systems of discrimination that may occur within this category: women, caste, trans, or capital. 
And so queer Sikhs struggle in configuring themselves as active agents in their religious communities. This situation leads them into complicated, if not problematic, associations with their own philosophy and it disrupts every way of socialization. They are most vulnerable and feel that their voices can easily go unheard. It becomes however important for them to assert and maintain both identities. As Sukhdeep Singh states in the interview annexed in this very same journal, he has "not come across a queer Sikh person who gave up their religious identity or religion because of their sexuality". He also mentions that he has met quite a few gay Sikh men "who did not see their religious and queer identities in conflict, because of the larger message of acceptance and equality of Sikh religion" (ibid.). It seems fundamental to bring such debate here because for queer Sikhs emancipating from their religion is sometimes a distant possibility. Unlike other scenarios that enjoy certain secularism, Sikhism emerges in an already effervescent context: colonialism, customary laws, domestic racism, traditionalism, orthodox practices. Finally, and at the risk of sounding little conventional, we borrow from Pattanaik (2017) and we attach here a series of enunciations that may illuminate whoever dissident Sikh is reading this paper. Pattanaik lists ten points from Karmic faiths that can be used to affirm the dignity of queer people. As they are very important to the acceptance of gender diversity and sexual orientation, we quote them entirely:

1. There is no concept of Judgement Day in any Karmic faith. God is no judge. There is no such thing as eternal damnation for anyone, which includes queer people.

2. Nature/God is infinite (ananta). Infinity has no boundaries (rekha), no divisions $(k h a n d a)$. It is fluid, like a river. It includes the queer. The human mind is finite and limited and so cannot understand everything. We have to accept even that which makes no sense to us, with love for and faith in the infinite.

3. Our body, our personality and our sexuality are outcomes of their karmic burden. They are therefore natural. Wisdom lies in accepting them as such rather than fighting them.

4. Knowledge helps us accommodate the queer in society. Every society has to change its rules as per the needs of geography (sthana), history (kala) and people (patra). In the past, women were seen as inferior to men, Dalits as inferior to Brahmins, and queers as inferior to straight people. But this is considered unacceptable in modern times. We have to change with the times.

5. We have to think in practical terms: a. How to include the queer in our family? b. Who will take care of the queer when he/she is old? c. How will the queer take care of old parents when they grow old? d. How will the queer take the family name forward?

6. Problems with the queer are the same problems we face with young men and women who are increasingly choosing career over family, singlehood over marriage, divorce over staying together, and preferring to have only one child. Old religious practices are being abandoned and new ways are emerging as boys and girls marry across religions, languages, castes and communities. This adjustment is no different from adjusting with queer people. 
7. Queer people can get married, for marriage is between souls (atma) that have no gender. We give too much value to the body (sharira) that can be male, female or queer.

8. No matter what our body (male, female, queer), no matter what our social status (rich/poor, educated/uneducated, married/unmarried, business/service), every human being has to cope with loneliness, sense of invalidation, and feelings of frustration and abandonment. This is universal for all creatures. Wisdom lies in helping people cope with this.

9. God is within us (jiva-atma) and others (para-atma). Through the other (para-atma) we can realise the infinite divine (param-atma). Hence the Upanishadic maxims: there is divinity within me (aham brahmasmi) and in you as well (tat tvam asi). To discover love and appreciation for the world as it is, not the way we want it to be, is wisdom. Discover God -that is wisdom and love- within you by being more generous and accepting of the queer in you and around you.

10. Everything in the eternal faiths (sanatana dharma) has a way out (upaay), nothing is fixed, provided we have open hearts, expanded minds, and are willing to 'adjust'. (51-52)

The reader can now start a new reading.

Review sent to author: 14/06/2021

Revised version accepted for publication: 12/07/2021 


\section{WORKS CITED}

Axel, Brian Keith. The Nation's Tortured Body: Violence, Representation, and the Formation of a Sikh Diaspora. Duke University Press, 2001.

Chanda, Anirbam \& Sahil Bansal. "The Punjabi Jatt Hero And Other Toxic Masculinities In Punjabi Culture." Feminism in India (10 June 2018). https://feminiminindia.com/2020/10/08/ punjabi-jatt-hero-toxic-masculinities-punjabi-culture. (Last accessed 15 June 2021).

Connell, Raewyn W. Gênero em termos. nVersos, 2016.

Connell, Raewyn W. "Globalization, Imperialism and Masculinities." Handbook of Studies on Men and Masculinities. Eds. Michael S. Kimmel, Jeff Hearn \& Raewyn W. Connell. Sage Publications, 2005. 71-89.

Cragun, Rayan T \& J. Edward Sumerau. “The Last Bastion of Sexual and Gender Prejudice? Sexualities, Race, Gender, Religiosity, and Spirituality in the Examination of Prejudice Toward Sexual and Gender Minorities." Journal of Sex Research (12 August 2014). https:// www.tandfonline.com/doi/abs/10.1080/00224499.2014.925534?journalCode=hjsr20. (Last accessed 10 February 2021).

Garha, Nachatter. "Masculinity in the Sikh Community in Italy and Spain: Expectations and Challenges. Religions (7 February 2020). https://www.mdpi.com/2077-1444/11/2/76. (Last accessed 15 June 2021).

Han, Enze \& Joseph O’Mahoney. "British colonialism and the criminalization of homosexuality." Cambridge Review of International Affairs (2 May 2014). https://www.tandfonline.com/doi/ abs/10.1080/09557571.2013.867298. (Last accessed 26 July 2020).

Hanif, Faisal. "My Muslim father tried exorcism to stop me being gay." The Times (3 November 2015). https://www.thetimes.co.uk/article/my-muslim-father-tried-exorcism-to-stop-mebeing-gay-sfhn0zxtd5g. (Last accessed 15 June 2021).

Humphreys, Laud. Out of the Closet: The Sociology of Homosexual Liberation. Prentice Hall, 1972.

India Untouched: Stories of a People Apart. Dir. Stalin Kurup, Video Volunteers, 2007. Youtube, https://www.youtube.com/watch?v=lgDGmYdhZvU.

Jankowics, Mia. "Jailed for using Grindr: homosexuality in Egypt.” The Guardian (3 April 2017). https://www.theguardian.com/global-development-professionals-network/2017/apr/03/ jailed-for-using-grindr-homosexuality-in-egypt. (Last accessed 4 April 2018).

Kalkra, Virinder S. "Locating the Sikh Pagh." Sikh Formations: Religion, Culture, Theory (19 August 2006). https://www.tandfonline.com/doi/abs/10.1080/17448720500132557. (Last accessed 15 June 2021).

Mahajan, Priyanka Thukral et al. "Indian religious concepts on sexuality and marriage." Indian journal of psychiatry (10 January 2013). https://www.ncbi.nlm.nih.gov/pmc/articles/ PMC3705692/. (Last accessed 23 August 2019).

Mustikan, Ahmar. "Forced marriages of LGBT+ people are a human rights abuse." Thomson Reuters Foundation News (11 March 2019). https://news.trust.org/item/20190307171959-kxdop/. (Last accessed 9 December 2019).

Pattanaik, Devdutt. "Introduction to the Karmic Faiths." I am Divine So Are you: How Buddhism, Jainism, Sikhism, and Hinduism affirm the dignity of queer identities and sexualities. Ed. Jerry Johson. HarperCollins, 2017. 25-52. 
Paur, Jasbir K. “'The Turban is not a Hat': Queer Diaspora and Practice of Profiling.” Beyond Biopolitics: Essays on the Governance of Life and Death. Ed. Patricia Ticineto Cough \& Craig Willse. Duke University Press, 2011.

"Power of Pride: Queer \& Sikh" Youtube, uploaded Logo TV (27 June 2019) https://www.youtube. com/watch?v=viZqLpdNWMg.

Preciado, Paul. "Multitudes queer.” Multitudes (10 May 2003). http://multitudes.samizdat.net/ Multitudes-queer. (Last accessed 6 March 2015).

Sab Rab De Bande (We're all God's Creation). Dir. Sukhdeep Singh, 2020a. Filmfreeway, https:// filmfreeway.com.

SANDERs, Eli. "Understanding turbans: Don't link them to terrorism." Seattle Times (27 September 2001). https://archive.seattletimes.com/archive/?date=20010927\&slug=turban270. (Last accessed 6 May 2020).

SEGATO, Rita Laura. Las estructuras elementales de la violencia: Ensayos sobre género entre antropología, el psiconálise, y los derechos humanos. Prometeo, 2010.

Singh, Pashaura. The Guru Granth Sahib: Canon, Meaning and Authority. Oxford University Press, 2000.

Singh, Khushwant. A History of the Sikhs Volume I: 1469-1839. Oxford University Press, 2016a.

Singh, Khushwant. A History of the Sikhs: Volume II: 1839-2004. Oxford University Press, 2016b.

Singh, Sukhdeep. "SAB RAB DE BANDE Q\&A w/ Dir. Sukhdeep Singh.” Doc. Vimeo, 2021. (Web 15 June 2021). https://vimeo.com/543299133.

SInGH, Sukhdeep. "Why I'm Making A Documentary On LGBTQ Sikhs (And Why It's Important)." Youth Ki Awaaz (11 February 2020a) https://www.youthkiawaaz.com/2020/02/why-iam-making-a-documentary-on-lgbtq-sikhs-and-why-it-is-important/. (Last accessed 15 June 2021).

SingH, Sukhdeep. "Sikhism: all humans are created equal." I am Divine So Are you: How Buddhism, Jainism, Sikhism, and Hinduism affirm the dignity of queer identities and sexualities. Ed. Jerry Johson. HarperCollins, 2017. 91-106.

SINGH, Sukhdeep. "Homophobia has no place in Sikhism." Gaylaxy (14 February 2016). http:// www.gaylaxymag.com/blogs/homophobia-has-no-place-in-sikhism/?fbclid=IwAR $\overline{3 c d} 2 \mathrm{j}$. (Last accessed 15 June 2021).

Singh, Sukhdeep. "Why LGBT Sikhs should come out.” Gaylaxy (7 May 2012). https://www. gaylaxymag.com/blogs/why-lgbt-sikhs-should-come-out/\#gs.58h6w5. (Last accessed 15 June 2021).

SinGH, Sukhdeep. "A New Dawn.” Gaylaxy (5 January 2010). https://www.gaylaxymag.com/gaylaxyissues/gaylaxy-jan-2010/\#gs.5vhfbj. (Last accessed 4 September 2018).

Singh, Sukhdeep. (Dir.). Sab Rab De Bande (We're all God's Creation). Filmfreeway, 2020b.

Singh, Sukhdeep. "I Want To Assure Other Young Queer Sikhs That One Could Be Gay and Sikh." Salzburg Global Seminar (1 September 2020c). https://www.salzburgglobal.org/news/latestnews/article/sukhdeep-singh-i-want-to-assure-other-young-queer-sikhs-that-one-could-begay-and-sikh. (Last accessed 15 June 2021).

ShIELD, Andrew DJ. "Grindr culture: Intersectional and socio-sexual." Ephemera: Theory and Politics (2018): np. http://www.ephemerajournal.org/sites/default/files/pdfs/contribution/181shield.pdf. 
Sidnu, Saminda. "What Is Sikhi? Who Are Sikhs?” The Gryphon (1 November 2019). https://www. thegryphon.co.uk/2019/11/01/what-is-sikhi-who-are-sikhs/. (Last accessed 15 June 2021).

TAYLOR, Yvette. Making Space for Queer-Identifying Religious Youth. Palgrave Mcmillan, 2016.

Sobel, Ariel. “Cameroon's Response to Lesbian 'Witches': Rape and Torture.” Advocate (2 October 2018). https://www.advocate.com/crime/2018/10/02/cameroons-response-lesbian-witchesrape-and-torture. (Last accessed 15 June 2021). 
